\title{
The Effect of Smartphone App-Based Interventions for Patients With Hypertension: Systematic Review and Meta-Analysis
}

\author{
Hongxuan $\mathrm{Xu}, \mathrm{MD}$; Huanyu Long, MD \\ Institute of Geriatric Medicine, Chinese Academy of Medical Sciences, Beijing, China

\section{Corresponding Author:} \\ Hongxuan $\mathrm{Xu}, \mathrm{MD}$ \\ The Key Laboratory of Geriatrics, Beijing Institute of Geriatrics, Beijing Hospital \\ National Center of Gerontology, National Health Commission \\ Institute of Geriatric Medicine, Chinese Academy of Medical Sciences \\ No 1 DaHua Road, Dong Dan \\ Beijing, 100730 \\ China \\ Phone: 8613524791942 \\ Email: xueramber@gmail.com
}

The Key Laboratory of Geriatrics, Beijing Institute of Geriatrics, Beijing Hospital, National Center of Gerontology, National Health Commission,

\begin{abstract}
Background: Hypertension is a major cause of cardiovascular disease, which is the leading cause of premature death. People with hypertension who do not comply with recommended treatment strategies have a higher risk of heart attacks and strokes, leading to hospitalization and consequently greater health care costs. The smartphone, which is now ubiquitous, offers a convenient tool to aid in the treatment of hypertension through the use of apps targeting lifestyle management, and such app-based interventions have shown promising results. In particular, recent evidence has shown the feasibility, acceptability, and success of digital interventions in changing the behavior of people with chronic conditions.
\end{abstract}

Objective: The aim of this study was to systematically compile available evidence to determine the overall effect of smartphone apps on blood pressure control, medication adherence, and lifestyle changes for people with hypertension.

Methods: This systematic review was conducted in accordance with the Preferred Reporting Items for Systematic Reviews and Meta-Analysis (PRISMA) statement guidelines. Databases were searched to identify randomized controlled trials related to the influence of an app-based intervention in people with hypertension. Data extracted from the included studies were subjected to a meta-analysis to compare the effects of the smartphone app intervention to a control.

Results: Eight studies with a total of 1657 participants fulfilled the inclusion criteria. Pooled analysis of 6 studies assessing systolic blood pressure showed a significant overall effect in favor of the smartphone intervention (weighted mean difference $-2.28,95 \%$ CI -3.90-0.66). Pooled analysis of studies assessing medication adherence demonstrated a significant effect $(P<.001)$ in favor of the intervention group (standard mean difference $0.38,95 \%$ CI $0.26-0.50)$ with low heterogeneity $\left(\mathrm{I}^{2}=0 \%\right)$. No difference between groups was demonstrated with respect to physical activity.

Conclusions: A smartphone intervention leads to a reduction in blood pressure and an increase in medication adherence for people with hypertension. Future research should focus on the effect of behavior coaching apps on medication adherence, lifestyle change, and blood pressure reduction.

(JMIR Mhealth Uhealth 2020;8(10):e21759) doi: $\underline{10.2196 / 21759}$

\section{KEYWORDS}

hypertension; smartphone; blood pressure; mobile; lifestyle; adherence; smartphone app; medication adherence

\section{Introduction}

Hypertension, or high blood pressure, is generally defined according to a systolic blood pressure (SBP) reading above 130/140 $\mathrm{mmHg}$ and/or diastolic blood pressure (DBP) above
$80 / 90 \mathrm{mmHg}$. Hypertension is a major cause of cardiovascular disease, which is the leading cause of premature death [1]. Hypertension affects approximately 244.5 million adults in China, only $15.3 \%$ of whom have their condition under control [2]. People with hypertension who do not comply with recommended treatment strategies have a higher risk of heart 
attacks and strokes, leading them to be hospitalized and left with greater health care costs [3]. Although faithfully taking prescribed medication and following suggested lifestyle changes can lead to a dramatic improvement in blood pressure, few people actually follow their doctor's advice, and thus fail to control their hypertension, leading to high rates of mortality and disability from heart conditions and other vascular diseases [4].

Self-measured blood pressure (SMBP) is believed to improve medication adherence, and is now a common intervention for hypertension management [5,6]. Lifestyle changes such as dietary sodium restriction, weight loss, and aerobic exercise can substantially decrease blood pressure [7]. In addition, the smartphone, which is found everywhere, offers a convenient tool to aid in the treatment of hypertension through the use of apps targeting lifestyle management, which have been showing promising results [8,9]. Recent evidence demonstrates the feasibility, acceptability, and success of digital interventions in changing the behavior of people with chronic conditions [10-17]. Getting one's hypertension under control may involve many lifestyle and behavioral changes. We hypothesized that smartphone apps combined with regular blood pressure monitoring and digital behavior change interventions may be more effective than currently employed hypertension management strategies.

Functions of such apps include a reminder to take one's medication, tracking a biometric result, education and motivation, and individualized coaching based on measured values and nonpharmaceutical behaviors. A large number of apps for medication adherence have become available in the last few years [18].

The primary objective of this systematic review and meta-analysis was to analyze the literature to determine the effect of smartphone apps on blood pressure control, medication adherence, and lifestyle changes. Only studies using stand-alone smartphone apps were included in the meta-analysis. Smartphone interventions that are not based on an app were excluded due to not conforming to our primary objective.

\section{Methods}

\section{Search Strategy}

This systematic review was conducted in accordance with the Preferred Reporting Items for Systematic Reviews and Meta-Analysis (PRISMA) statement guidelines [19].

We carried out a keyword search using the terms "smartphone," "hypertension," and "randomized controlled trials." The Ovid MEDLINE, EMBASE, PubMed, and Cochrane Library databases were searched from the start date of May 14, 2020. These databases were searched using a combination of subject headings (such as Medical Subject Headings) and filters (such as "RCT") when available. We also reviewed the references of included studies to identify additional pertinent studies. We imposed no language or time restriction.

\section{Inclusion and Exclusion Criteria}

Two reviewers independently assessed the records identified from the search for eligibility. Any discrepancies were resolved by consensus. We included any randomized controlled trials comparing smartphone apps-based hypertension management versus usual care or SMBP in adult primary hypertension patients. The target population was adults (aged 18 years and above) with hypertension (as defined by the authors). The outcome had to be objectively measured blood pressure changes. We accepted any duration of intervention.

We excluded studies of patients with confounding chronic conditions such as chronic kidney disease or diabetes mellitus, and those with missing key data. A protocol was developed prior to commencing this review on PROSPERO (CRD42020140926).

\section{Study Quality}

Study quality was assessed by the two authors based on the seven domains defined by the Cochrane Collaboration tool for assessing risk of bias [20]: (1) random sequence

generation; (2) allocation concealment; (3) blinding of participants and personnel; (4) blinding of outcome assessment; (5) incomplete outcome data; (6) selective reporting; and (7) other biases, including baseline imbalance, early stopping, and bias due to vested financial interest or academic bias.

Potential publication bias across studies was assessed using a funnel plot.

\section{Data Extraction}

One author (XX) extracted all data and both authors (XX and LY) reviewed the data for accuracy. The following data were collected: (1) country, duration of the trial, date of publication; (2) numbers of individuals included, inclusion criteria, exclusion criteria; (3) intervention, concomitant intervention; and (4) systolic/diastolic blood pressure change and behavior change (physical activity and medication adherence were the only two behaviors consistently reported in the existing literature).

\section{Data Synthesis}

\section{Meta-Analyses}

Meta-analysis was performed with Revman 5.3. We used a random-effects model and calculated the weighted mean difference (WMD) to generate pooled estimates of SBP and DBP changes; a random-effects model and standard mean difference (SMD) were used to calculate the intervention effects of medication adherence and physical activity across studies. We calculated the standard deviation using an assumption of a 0.5 correlation for studies that did not report the standard deviation of the mean of change, following the Cochrane Handbook for Systematic Reviews of Interventions [20]. The $\mathrm{I}^{2}$ statistic was used to assess the degree of statistical heterogeneity.

Blood pressure changes were divided into two subgroups based on the type of intervention. 


\section{Trial Sequential Analysis}

Trial sequential analysis is a methodology that considers how much information is needed to anticipate a specific required information size [21]. We used the TSA program version 0.9.5.10 Beta (Copenhagen Trial Unit) to adjust the CIs due to sparse data and repetitive testing of cumulative data, and to calculate the required information size. If the cumulative Z-curve crosses a trial sequential monitoring boundary or enters the futility area, it can be concluded that a sufficient level of evidence may have been reached. Conversely, the conclusion evidence is insufficient if the Z-curve does not cross any boundaries. The required information size was calculated based on autogenerated empirical data per input data. We performed the trial sequential analysis at the level of an overall 5\% risk of type I error and a power of $20 \%$.

\section{Sensitivity Analysis}

We conducted a posthoc sensitivity analysis to assess the impact of the potential reporting bias of trials with small sample sizes $(\mathrm{N}<60)$

\section{Results}

\section{Included Studies}

Eight studies [22-29] with a total of 1657 participants fulfilled the inclusion criteria; based on the results of sensitivity analysis, two studies [22,23] were excluded from the meta-analyses (Figure 1). SBP was assessed in 7 studies, DBP was assessed in 6 studies, medication adherence was assessed in 6 studies, and lifestyle changes were assessed in 2 studies. Characteristics of the included studies are summarized in Table 1.

The most common functions of mobile health apps were recording blood pressure, medication reminder, and abnormal values warning. Patient education or health recommendations were reported in 3 studies [23,25,29].

The follow-up period ranged from 6 weeks to 18 months, with a median of 6 months. Over $90 \%$ of participants were available for outcome assessment.

Figure 1. Preferred Reporting Items for Systematic Reviews and Meta-Analyses (PRISMA) flowchart of study selection.

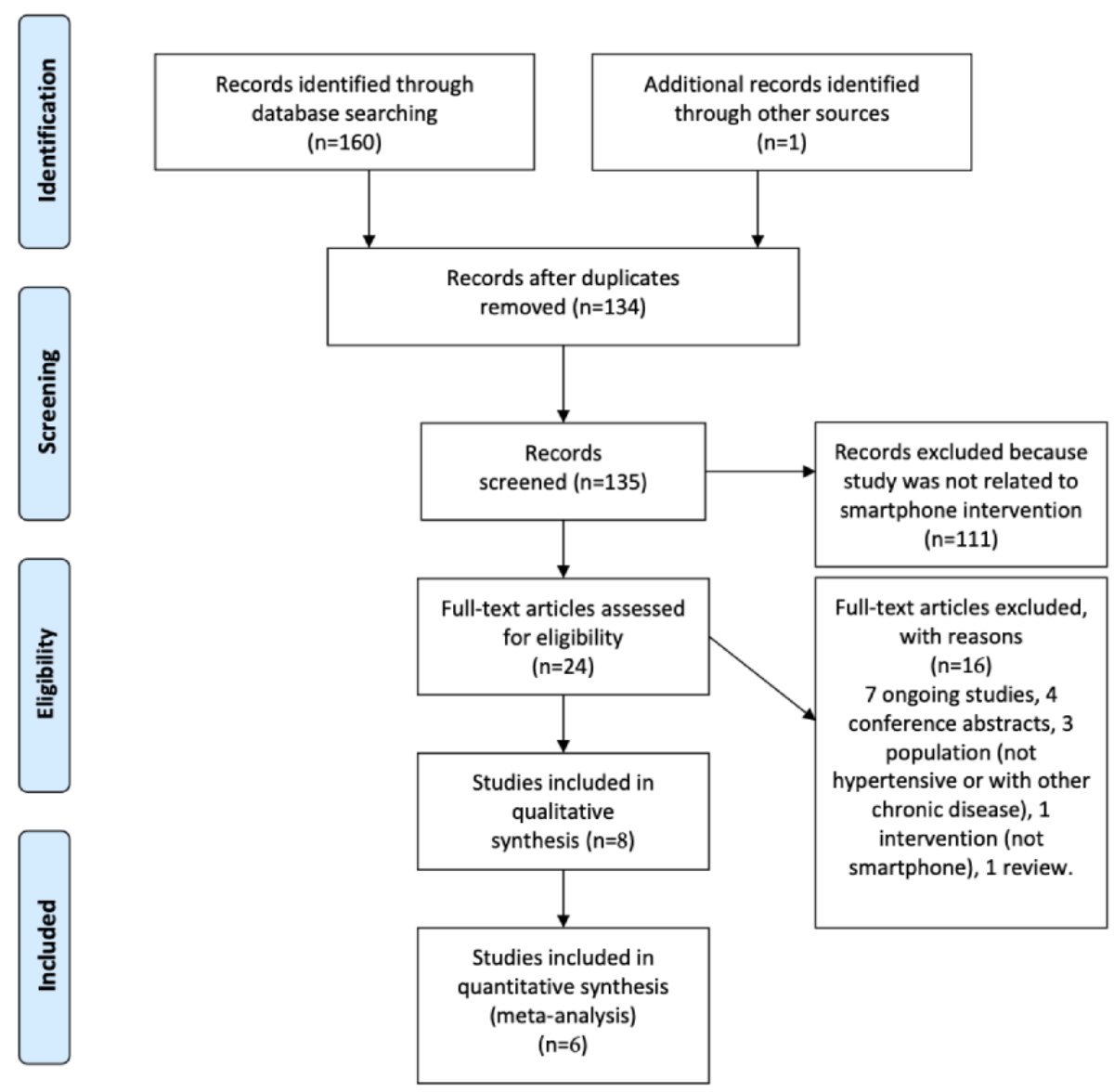


Table 1. Characteristics of included studies.

\begin{tabular}{|c|c|c|c|c|c|}
\hline Reference & Intervention & Control & Duration & Intervention protocol & Outcomes measured \\
\hline Persell et al [29] & $\begin{array}{l}\text { Hypertension Coach- } \\
\text { ing App, SMBP } \\
(\mathrm{n}=144)\end{array}$ & $\begin{array}{l}\mathrm{BP}^{\mathrm{b}} \text { tracking app, } \\
\mathrm{SMBP}(\mathrm{n}=152)\end{array}$ & 6 months & $\begin{array}{l}\text { Record (automatically } \\
\text { sync) BP daily for the } \\
\text { first week, then weekly } \\
\text { thereafter, along with } \\
\text { reminder, encourage- } \\
\text { ment, and education }\end{array}$ & $\mathrm{BP}$ \\
\hline Ghezeljeh et al [23] & $\begin{array}{l}\text { Social network self- } \\
\text { management educa- } \\
\text { tion }(n=25)\end{array}$ & $\begin{array}{l}\text { Regular routine educa- } \\
\text { tion }(n=25)\end{array}$ & 6 weeks & $\begin{array}{l}\text { Online education week- } \\
\text { ly }\end{array}$ & $M A^{c}$ \\
\hline Morawski et al [26] & $\begin{array}{l}\text { Medisafe app, SMBP } \\
(\mathrm{n}=209)\end{array}$ & None $(\mathrm{n}=202)$ & 12 weeks & Record BP, reminder & BP \\
\hline Logan et al [24] & $\begin{array}{l}\text { Telemonitoring Self- } \\
\text { Care Support System } \\
(\mathrm{n}=55)\end{array}$ & $\operatorname{SMBP}(\mathrm{n}=55)$ & 12 months & $\begin{array}{l}\text { Record BP twice a } \\
\text { week and twice in the } \\
\text { evening }\end{array}$ & $\mathrm{BP}$ \\
\hline Gong et al [28] & $\begin{array}{l}\text { Yan Fu app, SMBP } \\
(\mathrm{n}=225)\end{array}$ & $\begin{array}{l}\text { SMBP, record BP on } \\
\text { paper }(n=218)\end{array}$ & 6 months & $\begin{array}{l}\text { Record BP at least once } \\
\text { daily, reminder }\end{array}$ & BP, MA \\
\hline Chandler et al [22] & $\begin{array}{l}\text { SMASH app, SMBP } \\
(\mathrm{n}=28)\end{array}$ & $\begin{array}{l}\text { enhanced standard care } \\
(\mathrm{n}=26)\end{array}$ & 9 months & $\begin{array}{l}\text { Record (automatically } \\
\text { sync) BP every } 3 \text { days } \\
\text { in the morning and } \\
\text { evening, feedback }\end{array}$ & $\mathrm{BP}, \mathrm{MA}$ \\
\hline Kim et al [25] & $\begin{array}{l}\text { app, SMBP, online } \\
\text { disease management } \\
\text { program }(n=52)\end{array}$ & $\begin{array}{l}\text { usual care, online dis- } \\
\text { ease management pro- } \\
\text { gram }(n=43)\end{array}$ & 6 months & $\begin{array}{l}\text { Record BP } 3 \text { times a } \\
\text { week, } 2 \text { measurements } \\
\text { per day, health recom- } \\
\text { mendations, reminder }\end{array}$ & $\mathrm{BP}, \mathrm{MA}$ \\
\hline $\begin{array}{l}\text { Márquez Contreras et } \\
\text { al [27] }\end{array}$ & $\begin{array}{l}\text { ALERHTA app } \\
(\mathrm{n}=73)\end{array}$ & usual care $(\mathrm{n}=75)$ & $6 / 18$ months & Record BP, reminder & $\mathrm{BP}, \mathrm{MA}$ \\
\hline
\end{tabular}

${ }^{\mathrm{a}}$ SMBP: self-measured blood pressure.

${ }^{\mathrm{b}} \mathrm{BP}$ : blood pressure.

${ }^{\mathrm{c}}$ MA: medication adherence.

\section{Risk of Bias}

One study was judged to have a low risk of bias [24]. One study was judged to have a high risk of bias at one domain [29]. Results were unclear for the remaining 6 studies, mainly due to lack of detail of performance bias and selection bias (Multimedia Appendix 1).

\section{Blood Pressure}

Pooled outcomes of SBP (Figure 2) and DBP (Multimedia Appendix 1) were similar. SBP (WMD -2.28, 95\%CI $-3.90-0.66$; 6 studies $)$ with moderate heterogeneity $\left(\mathrm{I}^{2}=40 \%\right)$

and DBP (WMD $-1.84,95 \% \mathrm{CI}-3.49$ to $-0.19 ; 5$ studies) with moderate heterogeneity $\left(\mathrm{I}^{2}=54 \%\right)$ both showed a significant effect in favor of the intervention $(P=.006$ and $P=.03$, respectively). Blood pressure was significantly reduced in 4 studies $(-2.78 \mathrm{mmHg})$, but was not significantly reduced in 2 studies that included education in the intervention $(-0.33$ $\mathrm{mmHg}$ ).

Trial sequential analysis showed that the required information size of $20 \%$ power had been reached. The certainty of the evidence was high (Figure 3 ). 
Figure 2. Meta-analysis results and forest plot for the effect of app-based interventions on improvement in systolic blood pressure.

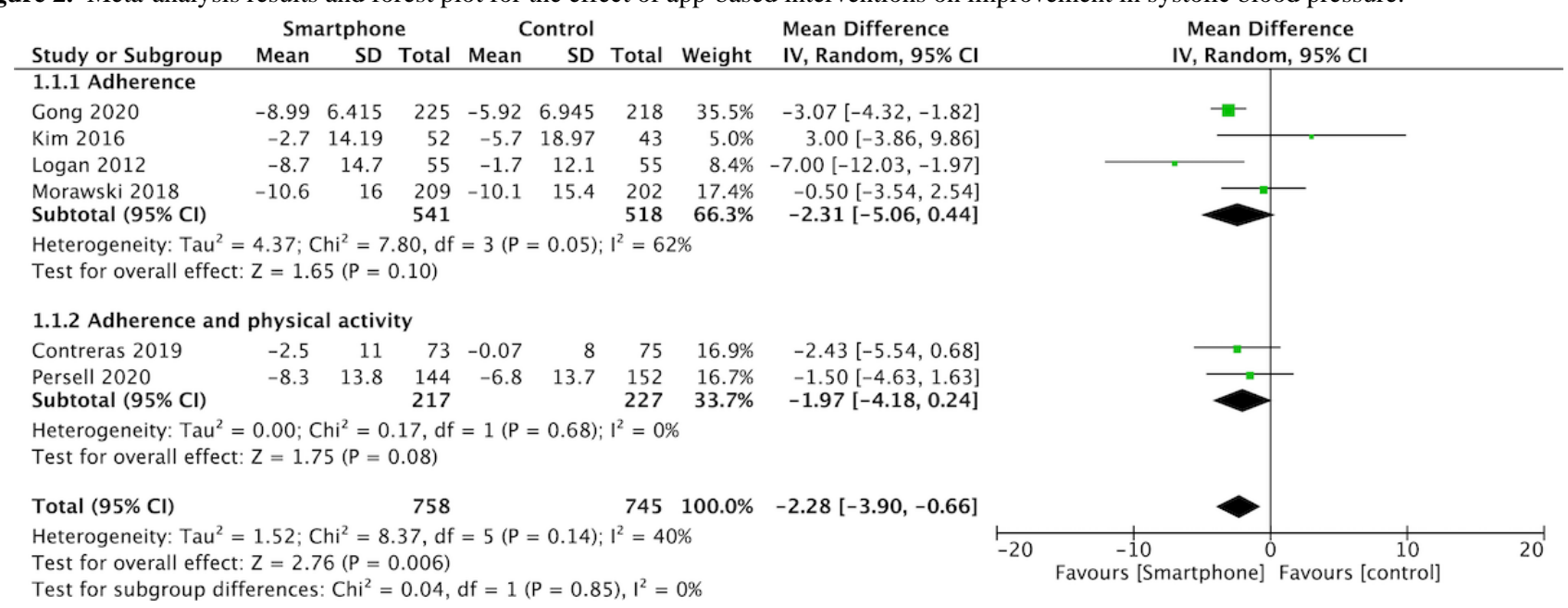

Figure 3. Trial sequential analysis of systolic blood pressure.

Required Information Size is a Two-sided graph

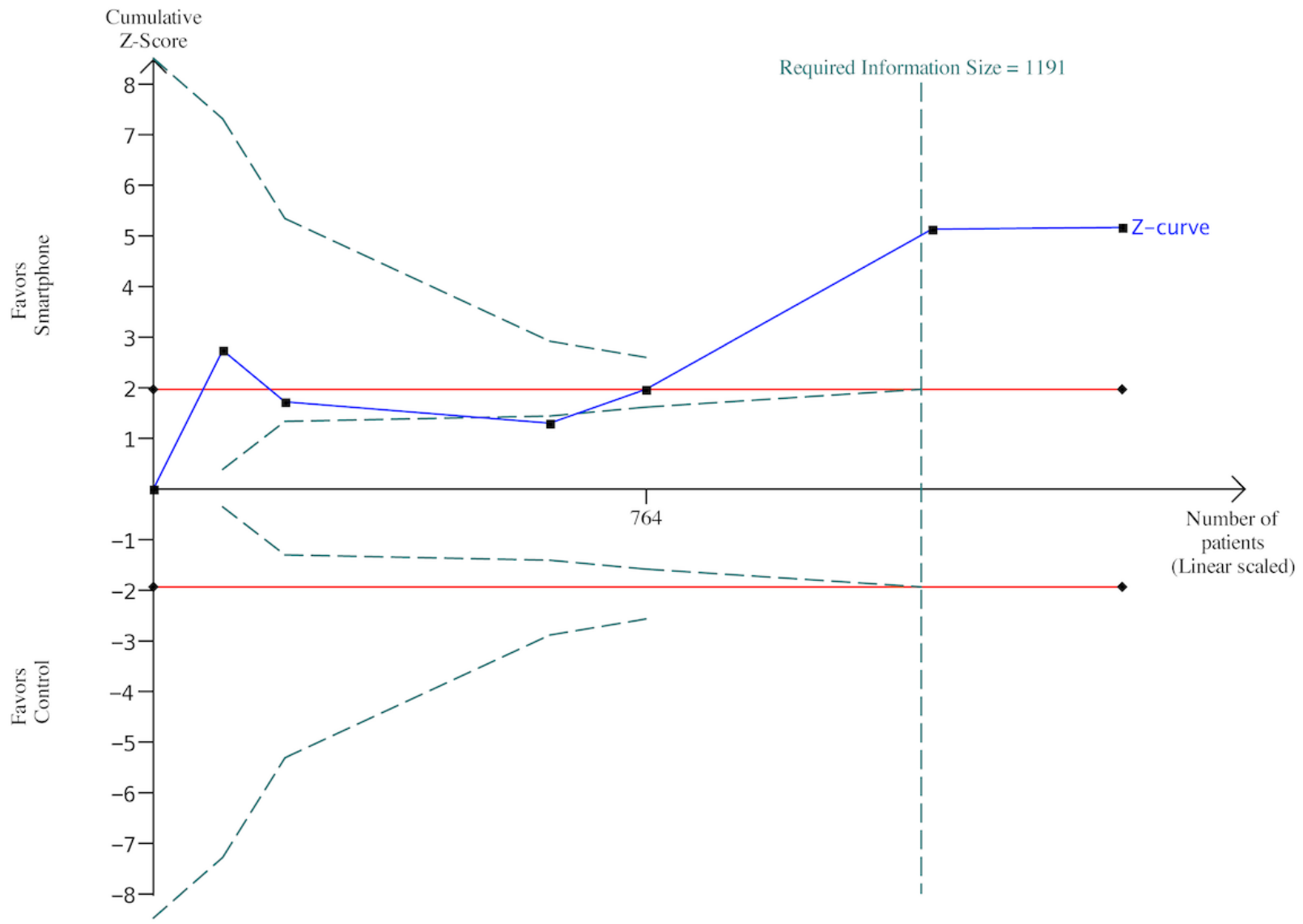

\section{Medication Adherence}

Four studies assessed medication adherence according to the Morisky Medication Adherence Scale-8 item (Figure 4) $[22,25,26,28]$, one study determined adherence based on the pill count [25], and the other used the Hypertension SM Behavior Questionnaire [23].
Pooled analysis of medication adherence demonstrated a significant effect $(P<0.0001)$ in favor of the intervention (SMD $0.38,95 \%$ CI $0.26-0.50)$ with low heterogeneity $\left(\mathrm{I}^{2}=0 \%\right)$.

A test for subgroup differences showed an insignificant effect when the studies were grouped $\left(\chi^{2}=1.70, \mathrm{df}=1, \mathrm{I}^{2}=41.3 \%\right)$. 
Figure 4. Meta-analysis and forest plot of the effect of the app-based intervention on medication adherence, assessed using the Morisky Medication Adherence Scale-8 item (4 studies).

\begin{tabular}{|c|c|c|c|c|c|c|c|}
\hline \multirow[b]{2}{*}{ Study or Subgroup } & \multicolumn{3}{|c|}{ Smartphone } & \multicolumn{3}{|c|}{ Control } & \multirow[b]{2}{*}{ Weight } \\
\hline & Mean & SD & Total & Mean & SD & Total & \\
\hline \multicolumn{8}{|l|}{$2.1 .1 \mathrm{BP}$ reduced } \\
\hline Contreras 2019 & 93.15 & 24.816 & 73 & 74.66 & 43.2025 & 75 & $13.1 \%$ \\
\hline Gong 2020 & 4.85 & 2.29 & 225 & 3.96 & 2.14 & 218 & $39.9 \%$ \\
\hline $\begin{array}{l}\text { Morawski } 2018 \\
\text { Subtotal }(95 \% \mathrm{Cl})\end{array}$ & 0.4 & 1.5 & $\begin{array}{l}209 \\
507\end{array}$ & -0.01 & 0.5 & $\begin{array}{l}202 \\
495\end{array}$ & $\begin{array}{l}37.1 \% \\
90.2 \%\end{array}$ \\
\hline \multicolumn{8}{|c|}{$\begin{array}{l}\text { Heterogeneity: } \mathrm{Tau}^{2}=0.00 ; \mathrm{Chi}^{2}=0.65, \mathrm{df}=2(\mathrm{P}=0.72) ; \mathrm{I}^{2}=0 \% \\
\text { Test for overall effect: } \mathrm{Z}=6.31(\mathrm{P}<0.00001)\end{array}$} \\
\hline \multicolumn{8}{|l|}{ 2.1.2 $\mathrm{BP}$ not reduce } \\
\hline $\begin{array}{l}\text { Kim } 2016 \\
\text { Subtotal }(95 \% \mathrm{CI})\end{array}$ & 6.7 & 1.4 & $\begin{array}{l}52 \\
52\end{array}$ & 6.5 & 1.5 & $\begin{array}{l}55 \\
55\end{array}$ & $\begin{array}{l}9.8 \% \\
9.8 \%\end{array}$ \\
\hline \multicolumn{8}{|c|}{$\begin{array}{l}\text { Heterogeneity: Not applicable } \\
\text { Test for overall effect: } Z=0.71(P=0.48)\end{array}$} \\
\hline Total $(95 \% \mathrm{Cl})$ & & & 559 & & & 550 & $100.0 \%$ \\
\hline \multicolumn{8}{|c|}{$\begin{array}{l}\text { Heterogeneity: } \mathrm{Tau}^{2}=0.00 ; \mathrm{Chi}^{2}=2.35, \mathrm{df}=3(\mathrm{P}=0.50) ; \mathrm{I}^{2}=0 \% \\
\text { Test for overall effect: } \mathrm{Z}=6.21(\mathrm{P}<0.00001)\end{array}$} \\
\hline
\end{tabular}

\section{Physical Activity}

Two studies reported physical activity [25,29]. Pooled analysis did not show a statistically significant effect of the intervention

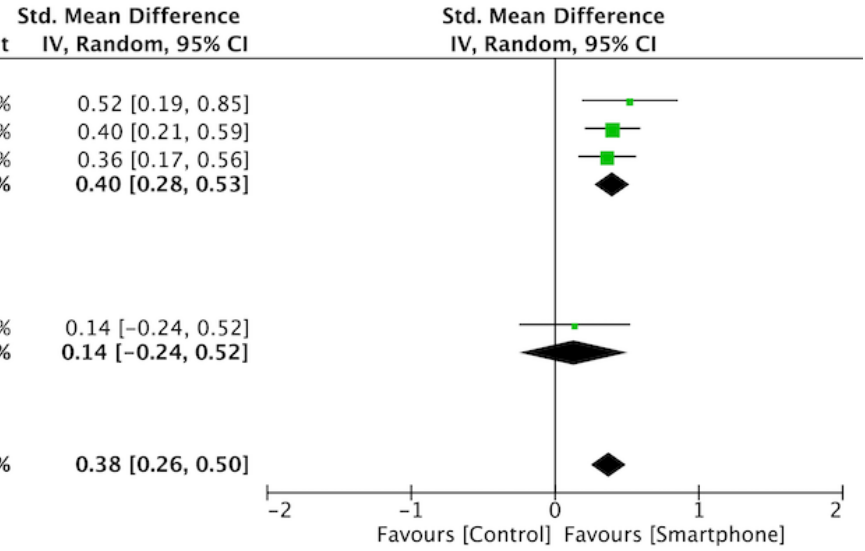

(SMD 0.12, 95\%CI -0.13-0.37, P=.33; Figure 5). One study showed a significant effect of reducing smoking [25] and one study showed a significant effect of confidence in controlling blood pressure [29].

Figure 5. Meta-analysis and forest plot of the effect of the app-based intervention on physical activity (2 studies).

\begin{tabular}{|c|c|c|c|c|c|c|c|c|c|c|}
\hline \multirow[b]{2}{*}{ Study or Subgroup } & \multicolumn{3}{|c|}{ Smartphone } & \multicolumn{3}{|c|}{ Control } & \multirow{2}{*}{\multicolumn{2}{|c|}{ Std. Mean Difference }} & \multirow{2}{*}{\multicolumn{2}{|c|}{$\begin{array}{l}\text { Std. Mean Difference } \\
\text { IV, Random, } 95 \% \mathrm{CI}\end{array}$}} \\
\hline & Mean & SD & Total & Mean & SD & Total & Weight & & & \\
\hline \multicolumn{11}{|c|}{ 3.1.1 Behavioral change } \\
\hline Kim 2016 & 39.8 & 23.8 & 52 & 41.3 & 29.5 & 43 & $29.8 \%$ & $-0.06[-0.46,0.35]$ & & \\
\hline $\begin{array}{l}\text { Persell } 2020 \\
\text { Subtotal }(95 \% \mathrm{Cl})\end{array}$ & 177.6 & 169.2 & $\begin{array}{l}144 \\
196\end{array}$ & 143.1 & 156.4 & $\begin{array}{l}152 \\
195\end{array}$ & $\begin{array}{r}70.2 \% \\
100.0 \%\end{array}$ & $\begin{array}{l}0.21[-0.02,0.44] \\
0.13[-0.11,0.37]\end{array}$ & & \\
\hline \multicolumn{11}{|c|}{$\begin{array}{l}\text { Heterogeneity: } \text { Tau }^{2}=0.01 ; \mathrm{Chi}^{2}=1.28, \mathrm{df}=1(\mathrm{P}=0.26) ; \mathrm{I}^{2}=22 \% \\
\text { Test for overall effect: } \mathrm{Z}=1.08(\mathrm{P}=0.28)\end{array}$} \\
\hline Total $(95 \% \mathrm{Cl})$ & & & 196 & & & 195 & $100.0 \%$ & $0.13[-0.11,0.37]$ & & \\
\hline \multicolumn{9}{|c|}{$\begin{array}{l}\text { Heterogeneity: } \mathrm{Tau}^{2}=0.01 ; \mathrm{Chi}^{2}=1.28, \mathrm{df}=1(\mathrm{P}=0.26) ; \mathrm{I}^{2}=22 \% \\
\text { Test for overall effect: } \mathrm{Z}=1.08(\mathrm{P}=0.28) \\
\text { Test for subgroup differences: Not applicable }\end{array}$} & $\begin{array}{cc}1 & 1 \\
-1 & 0 \\
\text { Favours [Control] } & \text { Favours }[\mathrm{Sm}\end{array}$ & $\begin{array}{l}1 \\
\text { a artphone] }\end{array}$ \\
\hline
\end{tabular}

\section{Discussion}

\section{Principal Findings}

We carried out this review to determine the effect of smartphone apps on the management of hypertension, and a pooled analysis of blood pressure and medication adherence of all studies demonstrated a significant effect in favor of the intervention. However, apps with digital behavior change interventions such as those targeting physical activity demonstrated little effect. The effect size of apps with behavioral instruction functions on blood pressure control was 9 times smaller than that of apps without these functions. Evidence of the impact of smartphone apps on physical activity was insufficient. Pooled analysis of two studies with insignificant blood pressure reduction via promoting physical activity showed a small but insignificant effect in favor of the intervention.

A previous review showed that SMBP alone is not associated with reducing blood pressure, whereas SMBP in conjunction with co-interventions significantly reduced blood pressure [6]. Another review showed that SMBP can lower blood pressure regardless of the number of hypertension-related comorbidities; however, for individuals with conditions such as obesity or stroke, SMBP should be combined with high-intensity co-interventions to effectively reduce blood pressure [30]. Moreover, individuals with chronic conditions using self-management digital interventions feel well cared for and tend to adopt a more active role in their health management [31]. Smartphone apps are able to integrate several co-interventions such as medication adherence, education, and lifestyle recommendations in one device. Our review indicated that SMBP in conjunction with a smartphone app improves medication adherence and reduces blood pressure. A reduction in SBP of $3 \mathrm{mmHg}$, as observed in intervention groups, would be expected to be associated with an $8 \%$ reduction in stroke mortality and a $5 \%$ reduction in mortality from coronary heart disease [1]. The observed magnitude of blood pressure reduction would have a significant impact on clinical practice considering the huge population worldwide suffering from hypertension.

A small minority of the apps included in our review incorporated educational functions, and the effect of these functions on blood pressure was insignificant. Available data on medication adherence of these studies was even more rare. The only study that reported medication adherence demonstrated an insignificant result. Yeung et al [32] found that in a low health literacy patient population, the use of educational tools such as flash cards and online videos significantly improved medication adherence in diabetes, hypertension, and heart failure patients. This study demonstrated that the successful education of patients regarding their medication use can significantly improve medication adherence. Medication nonadherence is estimated to cost the health care system US $\$ 5824$ annually per person among patients with hypertension [33]. Low adherence to antihypertension therapy among hospitalized patients was 
associated with increased costs of approximately US \$3574 (95\% CI US \$2897-\$4249) per person within a 3-year period [3]. This imposes a huge burden on the health care system and patients.

The lack of economic data such as the cost-effectiveness of smartphone-based interventions in improving medication adherence in patients with chronic health conditions highlights the need for further research to understand their role in cost savings while simultaneously improving medication adherence and health outcomes [34,35].

We have reason to believe that smartphone apps are feasible in general practice. Health care professionals should regard smartphone apps as potential tools for patients with hypertension to optimize management [36]. To better utilize these apps, several barriers need to be overcome, such as the generational difference in the propensity to use digital devices, lack of knowledge of available apps, ease of use of apps by the elderly, and privacy and data safety issues [36].

In our review, physical activity yielded an insignificant result. It is critical to discover how to usefully conceptualize and operationalize engagement with digital behavior change interventions. For instance, standardized terminology and measurement techniques will ensure more rapid advances in understanding engagement with digital behavior change interventions and developing methods to improve them [37]. The choice of app may be influenced by its immediate look and feel, "social proof," titles that appear realistic, and multicomponent features. Design features should focus on enhancing motivation, autonomy, personal relevance, and credibility [38-40].

It is vital that health care professionals and patients join together to form an effective and integrative relationship in clinical practice with mobile health apps.

\section{Limitations}

There were relatively few studies included in this meta-analysis. Therefore, the conclusions may be influenced by publication bias and should be regarded as preliminary. We did not include interventions that involved or targeted pediatric patients. The included trials were mainly conducted in North America and East Asia; thus, geographic unevenness may lead to underlying bias. Choice of the population such as excluding patients with mildly elevated blood pressure and different control interventions may also have yielded bias. With the various terms used to describe a digital intervention and its related health care, some studies may have been overlooked. The statistical findings should be interpreted cautiously for potential underlying heterogeneity.

\section{Conclusion}

A smartphone intervention leads to a reduction in blood pressure and an increase in medication adherence. Future research should discover the effect of behavior coaching apps on medication adherence, lifestyle change, and blood pressure reduction.

\section{Acknowledgments}

The authors thank AiMi Academic Services for English language editing and review services.

\section{Conflicts of Interest}

None declared.

\section{Multimedia Appendix 1}

Risk of bias assessment for the included studies and meta-analysis for the effect of a smartphone app intervention on diastolic blood pressure (DBP) improvement.

[DOCX File, 1261 KB-Multimedia Appendix 1]

\section{References}

1. Collins R, Peto R, MacMahon S, Hebert P, Fiebach NH, Eberlein KA, et al. Blood pressure, stroke, and coronary heart disease. Part 2, Short-term reductions in blood pressure: overview of randomised drug trials in their epidemiological context. Lancet 1990 Apr 07;335(8693):827-838. [doi: 10.1016/0140-6736(90)90944-z] [Medline: 1969567]

2. Wang Z, Chen Z, Zhang L, Wang X, Hao G, Zhang Z, China Hypertension Survey Investigators. Status of Hypertension in China: Results From the China Hypertension Survey, 2012-2015. Circulation 2018 May 29;137(22):2344-2356. [doi: 10.1161/CIRCULATIONAHA.117.032380] [Medline: 29449338]

3. Dragomir A, Côté R, Roy L, Blais L, Lalonde L, Bérard A, et al. Impact of adherence to antihypertensive agents on clinical outcomes and hospitalization costs. Med Care 2010 May;48(5):418-425. [doi: 10.1097/MLR.0b013e3181d567bd] [Medline: 20393367]

4. Benjamin EJ, Muntner P, Alonso A, Bittencourt MS, Callaway CW, Carson AP, American Heart Association Council on EpidemiologyPrevention Statistics CommitteeStroke Statistics Subcommittee. Heart Disease and Stroke Statistics-2019 Update: A Report From the American Heart Association. Circulation 2019 Mar 05;139(10):e56-e528. [doi: 10.1161/CIR.0000000000000659] [Medline: 30700139]

5. Fletcher BR, Hartmann-Boyce J, Hinton L, McManus RJ. The Effect of Self-Monitoring of Blood Pressure on Medication Adherence and Lifestyle Factors: A Systematic Review and Meta-Analysis. Am J Hypertens 2015 Oct;28(10):1209-1221. [doi: 10.1093/ajh/hpv008] [Medline: 25725092] 
6. Tucker KL, Sheppard JP, Stevens R, Bosworth HB, Bove A, Bray EP, et al. Self-monitoring of blood pressure in hypertension: A systematic review and individual patient data meta-analysis. PLoS Med 2017 Sep;14(9):e1002389 [FREE Full text] [doi: 10.1371/journal.pmed.1002389] [Medline: 28926573]

7. Whelton PK, Carey RM, Aronow WS, Casey DE, Collins KJ, Dennison Himmelfarb C, et al. 2017 ACC/AHA/AAPA/ABC/ACPM/AGS/APhA/ASH/ASPC/NMA/PCNA Guideline for the Prevention, Detection, Evaluation, and Management of High Blood Pressure in Adults: A Report of the American College of Cardiology/American Heart Association Task Force on Clinical Practice Guidelines. Hypertension 2018 Jun;71(6):e13-e115. [doi: 10.1161/HYP.0000000000000065] [Medline: 29133356]

8. Marko KI, Ganju N, Krapf JM, Gaba ND, Brown JA, Benham JJ, et al. A Mobile Prenatal Care App to Reduce In-Person Visits: Prospective Controlled Trial. JMIR Mhealth Uhealth 2019 May 01;7(5):e10520 [FREE Full text] [doi: 10.2196/10520] [Medline: $\underline{31042154]}$

9. Ek A, Alexandrou C, Söderström E, Bergman P, Delisle Nyström C, Direito A, et al. Effectiveness of a 3-Month Mobile Phone-Based Behavior Change Program on Active Transportation and Physical Activity in Adults: Randomized Controlled Trial. JMIR Mhealth Uhealth 2020 Jun 08;8(6):e18531 [FREE Full text] [doi: 10.2196/18531] [Medline: $\underline{32510462]}$

10. Payne HE, Lister C, West JH, Bernhardt JM. Behavioral functionality of mobile apps in health interventions: a systematic review of the literature. JMIR Mhealth Uhealth 2015 Feb 26;3(1):e20 [FREE Full text] [doi: 10.2196/mhealth.3335] [Medline: 25803705]

11. Thakkar J, Kurup R, Laba T, Santo K, Thiagalingam A, Rodgers A, et al. Mobile Telephone Text Messaging for Medication Adherence in Chronic Disease: A Meta-analysis. JAMA Intern Med 2016 Mar;176(3):340-349. [doi: 10.1001/jamainternmed.2015.7667] [Medline: 26831740]

12. Zhao J, Freeman B, Li M. Can Mobile Phone Apps Influence People's Health Behavior Change? An Evidence Review. J Med Internet Res 2016 Oct 31;18(11):e287 [FREE Full text] [doi: 10.2196/jmir.5692] [Medline: 27806926]

13. Badawy SM, Barrera L, Sinno MG, Kaviany S, O'Dwyer LC, Kuhns LM. Text Messaging and Mobile Phone Apps as Interventions to Improve Adherence in Adolescents With Chronic Health Conditions: A Systematic Review. JMIR Mhealth Uhealth 2017 May 15;5(5):e66 [FREE Full text] [doi: 10.2196/mhealth.7798] [Medline: 28506955]

14. Badawy SM, Kuhns LM. Texting and Mobile Phone App Interventions for Improving Adherence to Preventive Behavior in Adolescents: A Systematic Review. JMIR Mhealth Uhealth 2017 Apr 19;5(4):e50 [FREE Full text] [doi: 10.2196/mhealth.6837] [Medline: 28428157]

15. Badawy SM, Cronin RM, Hankins J, Crosby L, DeBaun M, Thompson AA, et al. Patient-Centered eHealth Interventions for Children, Adolescents, and Adults With Sickle Cell Disease: Systematic Review. J Med Internet Res 2018 Jul 19;20(7):e10940 [FREE Full text] [doi: 10.2196/10940] [Medline: 30026178]

16. Radovic A, Badawy SM. Technology Use for Adolescent Health and Wellness. Pediatrics 2020 May;145(Suppl 2):S186-S194. [doi: 10.1542/peds.2019-2056G] [Medline: 32358210]

17. Ramsey WA, Heidelberg RE, Gilbert AM, Heneghan MB, Badawy SM, Alberts NM. eHealth and mHealth interventions in pediatric cancer: A systematic review of interventions across the cancer continuum. Psychooncology 2020 Jan;29(1):17-37. [doi: 10.1002/pon.5280] [Medline: 31692183]

18. Dayer LE, Shilling R, Van Valkenburg M, Martin BC, Gubbins PO, Hadden K, et al. Assessing the Medication Adherence App Marketplace From the Health Professional and Consumer Vantage Points. JMIR Mhealth Uhealth 2017 Apr 19;5(4):e45 [FREE Full text] [doi: 10.2196/mhealth.6582] [Medline: 28428169]

19. Liberati A, Altman DG, Tetzlaff J, Mulrow C, Gøtzsche PC, Ioannidis JPA, et al. The PRISMA statement for reporting systematic reviews and meta-analyses of studies that evaluate health care interventions: explanation and elaboration. PLoS Med 2009 Jul 21;6(7):e1000100 [FREE Full text] [doi: 10.1371/journal.pmed.1000100] [Medline: 19621070]

20. Boutron I, Page MJ, Higgins JPT, Altman DG, Lundh A, Hróbjartsson A. Considering bias and conflicts of interest among the included studies. In: Higgins J, Green S, editors. Cochrane Handbook For Systematic Reviews Of Interventions. Hoboken, NJ: Wiley-Blackwell; 2019.

21. Thorlund K, Anema A, Mills E. Interpreting meta-analysis according to the adequacy of sample size. An example using isoniazid chemoprophylaxis for tuberculosis in purified protein derivative negative HIV-infected individuals. Clin Epidemiol 2010 Aug 09;2:57-66 [FREE Full text] [doi: 10.2147/clep.s9242] [Medline: 20865104]

22. Chandler J, Sox L, Kellam K, Feder L, Nemeth L, Treiber F. Impact of a Culturally Tailored mHealth Medication Regimen Self-Management Program upon Blood Pressure among Hypertensive Hispanic Adults. Int J Environ Res Public Health 2019 Apr 06;16(7):1226 [FREE Full text] [doi: 10.3390/ijerph16071226] [Medline: 30959858]

23. Najafi Ghezeljeh T, Sharifian S, Nasr Isfahani M, Haghani H. Comparing the effects of education using telephone follow-up and smartphone-based social networking follow-up on self-management behaviors among patients with hypertension. Contemp Nurse 2018;54(4-5):362-373. [doi: 10.1080/10376178.2018.1441730] [Medline: 29451091]

24. Logan AG, Irvine MJ, McIsaac WJ, Tisler A, Rossos PG, Easty A, et al. Effect of home blood pressure telemonitoring with self-care support on uncontrolled systolic hypertension in diabetics. Hypertension 2012 Jul;60(1):51-57. [doi:

10.1161/HYPERTENSIONAHA.111.188409] [Medline: 22615116]

25. Kim JY, Wineinger NE, Steinhubl SR. The Influence of Wireless Self-Monitoring Program on the Relationship Between Patient Activation and Health Behaviors, Medication Adherence, and Blood Pressure Levels in Hypertensive Patients: A 
Substudy of a Randomized Controlled Trial. J Med Internet Res 2016 Jun 22;18(6):e116 [FREE Full text] [doi: 10.2196/jmir.5429] [Medline: 27334418]

26. Morawski K, Ghazinouri R, Krumme A, Lauffenburger J, Lu Z, Durfee E, et al. Association of a Smartphone Application With Medication Adherence and Blood Pressure Control: The MedISAFE-BP Randomized Clinical Trial. JAMA Intern Med 2018 Jun 01;178(6):802-809 [FREE Full text] [doi: 10.1001/jamainternmed.2018.0447] [Medline: 29710289]

27. Márquez Contreras E, Márquez Rivero S, Rodríguez García E, López-García-Ramos L, Carlos Pastoriza Vilas J, Baldonedo Suárez A, Compliance Group of Spanish Society of Hypertension (SEH-LELHA). Specific hypertension smartphone application to improve medication adherence in hypertension: a cluster-randomized trial. Curr Med Res Opin 2019 Jan;35(1):167-173. [doi: 10.1080/03007995.2018.1549026] [Medline: 30431384]

28. Gong K, Yan Y, Li Y, Du J, Wang J, Han Y, et al. Mobile health applications for the management of primary hypertension: A multicenter, randomized, controlled trial. Medicine (Baltimore) 2020 Apr;99(16):e19715. [doi:

10.1097/MD.0000000000019715] [Medline: 32311957]

29. Persell SD, Peprah YA, Lipiszko D, Lee JY, Li JJ, Ciolino JD, et al. Effect of Home Blood Pressure Monitoring via a Smartphone Hypertension Coaching Application or Tracking Application on Adults With Uncontrolled Hypertension: A Randomized Clinical Trial. JAMA Netw Open 2020 Mar 02;3(3):e200255 [FREE Full text] [doi: 10.1001/jamanetworkopen.2020.0255] [Medline: 32119093]

30. Sheppard JP, Tucker KL, Davison WJ, Stevens R, Aekplakorn W, Bosworth HB, et al. Self-monitoring of Blood Pressure in Patients With Hypertension-Related Multi-morbidity: Systematic Review and Individual Patient Data Meta-analysis. Am J Hypertens 2020 Mar 13;33(3):243-251 [FREE Full text] [doi: 10.1093/ajh/hpz182] [Medline: 31730171]

31. Morton K, Dennison L, May C, Murray E, Little P, McManus RJ, et al. Using digital interventions for self-management of chronic physical health conditions: A meta-ethnography review of published studies. Patient Educ Couns 2017 Apr;100(4):616-635 [FREE Full text] [doi: 10.1016/j.pec.2016.10.019] [Medline: 28029572]

32. Yeung DL, Alvarez KS, Quinones ME, Clark CA, Oliver GH, Alvarez CA, et al. J Am Pharm Assoc 2017 Jan;57(1):30-37 [FREE Full text] [doi: 10.1016/j.japh.2016.08.012] [Medline: 27816544]

33. Lloyd JT, Maresh S, Powers CA, Shrank WH, Alley DE. How Much Does Medication Nonadherence Cost the Medicare Fee-for-Service Program? Med Care 2019 Mar;57(3):218-224. [doi: 10.1097/MLR.0000000000001067] [Medline: 30676355]

34. Badawy SM, Kuhns LM. Economic Evaluation of Text-Messaging and Smartphone-Based Interventions to Improve Medication Adherence in Adolescents with Chronic Health Conditions: A Systematic Review. JMIR Mhealth Uhealth 2016 Oct 25;4(4):e121 [FREE Full text] [doi: 10.2196/mhealth.6425] [Medline: 27780795]

35. Iribarren SJ, Cato K, Falzon L, Stone PW. What is the economic evidence for mHealth? A systematic review of economic evaluations of mHealth solutions. PLoS One 2017;12(2):e0170581 [FREE Full text] [doi: 10.1371/journal.pone.0170581] [Medline: 28152012]

36. Byambasuren O, Beller E, Hoffmann T, Glasziou P. Barriers to and Facilitators of the Prescription of mHealth Apps in Australian General Practice: Qualitative Study. JMIR Mhealth Uhealth 2020 Jul 30;8(7):e17447 [FREE Full text] [doi: 10.2196/17447] [Medline: 32729839$]$

37. Perski O, Blandford A, West R, Michie S. Conceptualising engagement with digital behaviour change interventions: a systematic review using principles from critical interpretive synthesis. Transl Behav Med 2017 Jun;7(2):254-267 [FREE Full text] [doi: 10.1007/s13142-016-0453-1] [Medline: 27966189]

38. Badawy SM, Thompson AA, Liem RI. Technology Access and Smartphone App Preferences for Medication Adherence in Adolescents and Young Adults With Sickle Cell Disease. Pediatr Blood Cancer 2016 May;63(5):848-852. [doi: 10.1002/pbc.25905] [Medline: 26844685]

39. Badawy SM, Thompson AA, Kuhns LM. Medication Adherence and Technology-Based Interventions for Adolescents With Chronic Health Conditions: A Few Key Considerations. JMIR Mhealth Uhealth 2017 Dec 22;5(12):e202 [FREE Full text] [doi: 10.2196/mhealth.8310] [Medline: 29273573]

40. Perski O, Blandford A, Ubhi HK, West R, Michie S. Smokers' and drinkers' choice of smartphone applications and expectations of engagement: a think aloud and interview study. BMC Med Inform Decis Mak 2017 Feb 28;17(1):25 [FREE Full text] [doi: 10.1186/s12911-017-0422-8] [Medline: 28241759]

\section{Abbreviations}

DBP: diastolic blood pressure

PRISMA: Preferred Reporting Items for Systematic Reviews and Meta-Analysis

SBP: systolic blood pressure

SMBP: self-measuring blood pressure

SMD: standard mean difference

WMD: weighted mean difference 
Edited by G Eysenbach; submitted 24.06.20; peer-reviewed by S Badawy, P Cook; comments to author 09.08.20; revised version received 07.09.20; accepted 12.09.20; published 19.10.20

Please cite as:

$X u$ H, Long $H$

The Effect of Smartphone App-Based Interventions for Patients With Hypertension: Systematic Review and Meta-Analysis JMIR Mhealth Uhealth 2020;8(10):e21759

URL: http://mhealth.jmir.org/2020/10/e21759/

doi: $10.2196 / 21759$

PMID: 33074161

CHongxuan Xu, Huanyu Long. Originally published in JMIR mHealth and uHealth (http://mhealth.jmir.org), 19.10.2020. This is an open-access article distributed under the terms of the Creative Commons Attribution License (https://creativecommons.org/licenses/by/4.0/), which permits unrestricted use, distribution, and reproduction in any medium, provided the original work, first published in JMIR mHealth and uHealth, is properly cited. The complete bibliographic information, a link to the original publication on http://mhealth.jmir.org/, as well as this copyright and license information must be included. 